\author{
Krzysztof Cyran \\ Akademia Muzyczna im. Krzysztofa Pendereckiego w Krakowie \\ https://orcid.org/0000-0003-2509-873X \\ krzysztof.cyran@amuz.krakow.pl
}

\title{
Wymiary czasu, dźwięku i ciszy. Krzysztof Penderecki i sacrum ${ }^{1}$
}

\author{
„Moja sztuka, wyrastając z korzeni głęboko chrześcijańskich, dąży do \\ odbudowania metafizycznej przestrzeni człowieka \\ strzaskanej przez kataklizmy XX wieku. \\ Przywrócenie wymiaru sakralnego rzeczywistości \\ jest jedynym sposobem uratowania człowieka” ${ }^{2}$. \\ Krzysztof Penderecki
}

Twórczość Krzysztofa Pendereckiego stanowi w polskiej muzyce zjawisko osobne. Rok po odejściu kompozytora wydaje się dystansem zbyt krótkim, by pokusić się o syntezę tak obszernego i zróżnicowanego dorobku. Warto jednak przypomnieć, iż w całej bibliotece tekstów składających się na zjawisko recepcji kulturowej, obok kilku biografii oraz niezliczonych prac o charakterze zarówno naukowym, jak i popularnym, znajdują się także istotne studia podsumowujące kluczowe wątki w twórczości artysty ${ }^{3}$.

Bez wątpienia wśród owych wątków kluczowych na czoło wysuwa się problematyka tematyki religijnej. Przenika ona całą drogę twórczą kompozytora, stanowiąc bodaj najistotniejszy jej nurt. Przez ponad pół wieku, od Psalmów Dawida (1959) do Dies illa (2014) Penderecki, odwołując się do rozmaitych tradycji gatunkowych, podnosi najbardziej współczesne dylematy, po swojemu nie tylko

1 Tytuł artykułu nawiązuje do kompozycji Krzysztofa Pendereckiego Wymiary czasu i ciszy z 1960 roku.

2 K. Penderecki, Labirynt czasu. Pięć wyktadów na koniec wieku, Warszawa 1997.

3 R. Chłopicka, Krzysztof Penderecki między sacrum a profanum: studia nad twórczościa wokalno-instrumentalna, Kraków 2000; Krzysztof Penderecki - muzyka ery intertekstualnej. Studia i interpretacje, red. M. Tomaszewski, E. Siemdaj, Kraków 2005; M. Tomaszewski, Penderecki. Bunt i wyzwolenie, t. 1-2, Kraków 2008-2009 (Kompozytorzy Polscy XX Wieku). 
dialogując, ale i „wadząc się z Bogiem”. Sacrum i jego artystyczne realizacje mienią się u niego mnogością odcieni, nie są nigdy jednowymiarowe. Można zaryzykować tezę, iż przemiany w twórczości religijnej kompozytora dokonywały się równolegle z kolejnymi etapami przeobrażeń jego stylu w ogóle ${ }^{4}$.

Jak już powiedziano, za wcześnie jeszcze na szerszą syntezę. Można jednak próbować, nawet ułomnie i szkicowo, uchwycić najważniejsze idee, które zdają się stać u podstaw tak rozległego repertuaru inspirowanego sferą sacrum ${ }^{5}$.

Za punkt wyjścia przyjąć warto istotną myśl Władysława Stróżewskiego: „Twórczość Pendereckiego jest to wielka muzyczna realizacja dialektyczności. Dialektyczności rozpiętej między ekstremami, jakoś znoszącej te ekstrema, ale przy jednoczesnym stałym utrzymywaniu ich istnienia" ${ }^{6}$. Mając to na uwadze, łatwiej dostrzec związki abstrakcyjnych studiów czasowo-przestrzennych nad malarstwem Paula Klee z badaniem pogłosu katedry w Münster, czy zobaczyć troskę o „dziedzictwo, któremu na imię Polska” w całej - wyjątkowo rozległej - panoramie wyznaczonej przez silnie naznaczone tradycją sacrum Polskiego Requiem oraz drastyczne profanum Ubu Króla.

By możliwie najszerzej ująć problematykę sacrum, chciałbym odwołać się do przytoczonej na samym początku jako motto, jednej z najczęściej cytowanych wypowiedzi Krzysztofa Pendereckiego, oraz skupić się na obecnych tam dwóch, moim zdaniem kluczowych, metaforach. „Metafizyczna przestrzeń człowieka” i „wymiar sakralny rzeczywistości” są pojęciami nietożsamymi, lecz komplementarnymi.

4 Ta relacja między religijną a świecką muzyką u Pendereckiego wydaje się szczególnym przypadkiem ogólniejszej zasady: ks. Joachim Waloszek, za Heinrichem Besselerem i Oskarem Sohngenem, przypomina: „(...) okresy świetności muzyki kościelnej w historii muzyki (...): szkoły Notre Dame, epoka Dufaya ze staroniderlandzką missa-chanson oraz epoka J.S. Bacha to akurat takie epoki, które posługują się identycznym językiem muzycznym w kompozycjach sakralnych i świeckich. Prawdziwy klucz do zrozumienia sakralnej wartości i doskonałości języka muzycznego tych (...) epok leży (...) w tym, iż w całym obszarze poetyki muzycznej (...) obowiązywały wtedy idee podkreślające obiektywny wymiar i obiektywne znaczenie "zjawiska» muzycznego" (J. Waloszek, Teologia muzyki. Wspótczesna myśl teologiczna o muzyce, Opole 1997, s. 268).

5 Ksiądz Jacek Bramorski, teolog i muzyk, zwraca uwagę, że używając terminu „sztuka sakralna”, należy także odnieść się do samego pojęcia sacrum. Autor z pozycji chrześcijańskiej teologii muzyki wskazuje owego pojęcia cztery elementy konstytutywne: transcendencję (sacrum przekracza to, co doczesne), rzeczywistość (nie jest abstrakcyjną ideą, ale rzeczywiście istnieje), świętość (odznacza się charakterem boskim), sens personalistyczny (ma cechy osobowe, czyli świadomość i wolność oraz zdolność nawiązywania dialogowego kontaktu), za: J. Bramorski, Teologiczno-estetyczne wyznaczniki sakralności dzieta muzycznego, „Pro Musica Sacra” (2013) nr 11, s. 13.

${ }^{6}$ M. Tomaszewski, Penderecki. Bunt i wyzwolenie, t. 1: Rozpętanie żywiotów, Kraków 2008, s. 19 (Kompozytorzy Polscy XX Wieku). 
Uprzytamniając rzeczy oczywiste: człowiek zadaje pytania z jednej strony o istotę, z drugiej o sens i cel zarówno swojej własnej egzystencji, jak i całego świata. Pytanie: „kim jestem?” nieuchronnie prowadzi do pytań „skąd” i „ku czemu jestem”, a dalej rozszerza się na całe uniwersum. Jak powszechnie wiadomo, różnice w kategoryzacji, a także rozmaitość możliwych odpowiedzi, nie zmieniają natury samych owych pytań, które zazwyczaj noszą nazwę metafizycznych. $\mathrm{Z}$ ich właśnie pomocą człowiek buduje sam dla siebie ową „metafizyczną przestrzeń”. Nie trzeba dodawać, że wspomniane przez Pendereckiego „strzaskanie” dotyczyło zakwestionowania zarówno wartości osoby ludzkiej, jak i sensu oraz celu jej istnienia.

W owej zatem przestrzeni metafizycznej odnaleźć można wymiar, często nazywany sakralnym. W najszerszym rozumieniu da się go określić jako wrażliwość na tzw. inny świat. Jak pisałem w innym moim tekście:

Pojęcie sacrum, mimo pewnej migotliwości, dobrze oddaje intuicyjnie wyczuwany obszar doświadczenia ludzkiego, definiowany również negatywnie jako „nad-przyrodzony”, „ponad-zmysłowy”, czy „trans-cendentny”".

Jak to ujmuje Mircea Eliade, sacrum i profanum są dwoma odrębnymi sposobami życia w świecie ${ }^{8}$. Jego diagnoza o postępującej w XX w. desakralizacji (profanizacji, sekularyzacji) nie jest odosobniona. Niektórzy - w tym Krzysztof Penderecki w przytoczonej wypowiedzi - za główną jej przyczynę uznają „kataklizmy XX wieku", czyli wojny i systemy totalitarne9. Ale Eliade, abstrahując od wymiaru historycznego, wskazuje na coś więcej: o ile dla człowieka o naturze świeckiej wymiar sakralny jest czymś nieistotnym, niekoniecznym, irracjonalnym, a przez to ontologicznie niestabilnym, o tyle człowiek żyjący w sferze świętości traktuje ją jako wymiar najważniejszy i niezbywalny: „we wszystkich społecznościach przednowożytnych świętość oznacza tyle, co siła, a ostatecznie także po prostu rzeczywistość (...). Święta siła oznacza tyle co rzeczywistość, wieczność i skuteczność w jednym" ${ }^{10}$.

Wynika z tego jasno, że utrata - z jakichkolwiek przyczyn - wymiaru sakralnego dla człowieka religijnego jest katastrofą par excellence, sięgającą podstaw egzystencji,

7 K. Cyran, „Kanon i postmodernizm” $w$ twórczości religijnej kompozytorów polskich przetomu XX i XXI wieku, Kraków 2015, s. 39 (niepublikowana praca doktorska pod kierunkiem prof. Teresy Maleckiej).

8 M. Eliade, Sacrum i profanum. O istocie religijności, tłum. R. Reszke, Warszawa 1999.

9 Szerokim echem odbiło się poznańskie przemówienie Krzysztofa Pendereckiego z okazji przyznania doktoratu honoris causa UAM w roku 1987, krytykujące „oba systemy - czarny i czerwony”. Zob. M. Tomaszewski, Penderecki. Bunt i wyzwolenie, t. 1, s. 17.

10 M. Eliade, Sacrum i profanum, s. 8. 
jest losem tragicznym. „Człowiek religijny - pisze Eliade - zawsze stara się żyć w świętym Uniwersum (...) i w rezultacie tego całe jego przeżywanie jest całkiem inne niż człowieka pozbawionego uczucia religijnego (...)"11.

W zdesakralizowanym świecie sytuacja diametralnie się zmienia. Autor mówi o „otchłani”, która zieje między doświadczeniem religijnym a doświadczeniem świeckim. Jak pisze:

Wystarczy pomyśleć tylko, czym dla współczesnego, niereligijnego człowieka stały się miasto i dom, natura, narzędzia i praca, by w okamgnieniu zrozumieć, co odróżnia go od człowieka społeczności archaicznych, lecz również od chłopa żyjącego w chrześcijańskiej Europie ${ }^{12}$.

A zatem, odbudowywanie przestrzeni metafizycznej nie może się obyć bez dramatu: trzeba zbudować „most nad otchłanią” między światem sacrum a profanum. Tę właśnie rolę spełnić może sztuka.

Można powiedzieć, że Krzysztof Penderecki był jednym z artystów, którzy w dążeniu do tego celu podjęli trud „przemyślenia podstaw naszej kultury od nowa" ${ }^{13}$, niejako avant a lettre, zanim postmoderniści wypisali owo hasło na swoich sztandarach. Wydaje się więc, iż maksymalistyczny zakres problematyki metafizycznej u Pendereckiego bierze się właśnie z przekonania o potrzebie refleksji fundamentalnej.

\section{Liczba}

Penderecki nieraz w tytułach swych dzieł sięgał po pojęcie arche - prazasady, prapoczątku, przyczyny wszechrzeczy ${ }^{14}$. Szukając w jego partyturach owej prazasady trudno się oprzeć wrażeniu, iż jest nią ta, na którą wskazywał Pitagoras - liczba. Wszak to jeden z tajemniczych wymiarów bytu, jasno pokazujący fenomen nieskończoności, a opisująca go nauka - matematyka, zdaniem ks. Michała Hellera jest jedyną działalnością człowieka wolną od grzechu pierworodnego ${ }^{15}$.

\footnotetext{
11 M. Eliade, Sacrum i profanum, s. 9.

12 M. Eliade, Sacrum i profanum, s. 9-10.

13 Por. A. Szahaj, Ponowoczesność - czas karnawatu. Postmodernizm - filozofia btazna?, w: Postmodernizm a filozofia. Wybór tekstów, red. S. Czerniak, A. Szahaj, Warszawa 1996, s. 389.

14 Kosmogonia (1970), części: Arche, Apeiron; I Symfonia (1973), części: Arche 1, Dynamis 1, Dynamis 2, Arche 2.

15 „[Ks. Michał Heller] lubi powtarzać, że wysoka matematyka to jedyna dziedzina nieskażona grzechem pierworodnym. Że żal mu ludzi, którzy jej nie znają, bo nigdy nie doświadczą piękna w najczystszej postaci. Że to nauka, która «wydobywa ukryte struktury rzeczywistości i wnika
} 
Liczba u Pendereckiego porządkuje rozmaite wymiary muzyki: interwały, rytmy, faktury; daje świadectwo mistrzostwa warsztatowego i spójności brzmieniowej. We wszystkich fazach jego twórczości, przy zmieniających się technikach i stylach, układy liczbowe - na różne sposoby - porządkują formę utworów. Jest to jednak coś więcej niż tylko matematyka. Przykładów można szukać w organizacji interwałów: z jednej strony, ugrupowania takie jak „akord Pendereckiego” (oznaczony formułą 6313), czy „motyw trytonów” (616161), pomimo odwołań do techniki dwunastotonowej stanowią kompleksy brzmieniowe o wyjątkowo wyrazistej barwie. $Z$ drugiej zaś, w strefie stosunkowo łagodniejszych (stopliwych ${ }^{16}$ ) brzmień, drobne z matematycznego punktu widzenia przesunięcie o półton tworzy znaczące napięcie wynikające $\mathrm{z}$ „zakłócenia” prostych układów trójdźwiękowych i oktawowo-kwintowych (np. c-es-as-g lub c-g-des $\left.{ }_{1}-\mathrm{c}_{1}\right)^{17}$.

Powszechnie znane (i opisane) jest także zjawisko wykorzystywania przez kompozytora symbolicznych własności pewnych interwałów (oktawa i tryton w Raju utraconym ${ }^{18}$ lub samych liczb (Siedem bram Jerozolimy) ${ }^{19}$, nawiązujące wprost do tysiącletniej tradycji muzyki Zachodu.

\section{Od dźwięków do parametrów i z powrotem - kwestia ekspresji}

Doświadczenie serializmu, które uformowało Krzysztofa Pendereckiego wraz z całym pokoleniem, jego samego z pewnością nigdy całkowicie nie „sformatowało”. Dokonujące się w Darmstadt odkrycia w zakresie tzw. muzyki nowej, na podobieństwo atomowej fuzji łączące zagadnienia serii interwałowych, generowania nowych brzmień oraz nowych sposobów rejestracji i obróbki dźwięku, doprowadziło muzykę na skraj parametryzacji, a więc dominacji wielkości mierzalnych: melodia i harmonia zamieniła się w wykres fali dźwiękowej, rytm - w sekundową siatkę impulsów, dynamika - w zmianę poziomu głośności. Penderecki był żywo zainteresowany

w głęboką strukturę świata, gołym okiem niewidoczną»”, za: E. Isakiewicz, Harmonia sfer, „Tygodnik Powszechny" (2008) nr 11, s. 6. Ten fragment przemówienia zacytował także w swoim wystąpieniu doktora honoris causa w 2008 roku Henryk Mikołaj Górecki, zob. przypis 48.

16 Tadeusz A. Zieliński w pracy Podstawy harmoniki nowoczesnej (1983), pisząc o harmonii $\mathrm{XX}$ wieku, proponuje zamienić parę punktowych, wykluczających się pojęć „konsonans-dysonans” na liniowe stopniowanie jakości brzmienia na osi „selektywne (ostre) - stopliwe (łagodne)”. 17 Tak konstruowane układy, zarówno w wersji melodycznej, jak i harmonicznej, są istotną częścią motywiki Siedmiu bram Jerozolimy (1996), Credo (1998), VIII Symfonii „Pieśni przemijania" (2007).

18 Por. R. Chłopicka, Krzysztof Penderecki między sacrum a profanum, s. 90-91.

19 Por. R. Chłopicka, Krzysztof Penderecki między sacrum a profanum, s. 109-111. 
wszelkimi nowinami, z elektroniką włącznie ${ }^{20}$, jednak w polu jego zainteresowań znajdowało się zawsze coś więcej. Po latach Pierre Boulez wspominając ów okres porównywał serializm do „czegoś w rodzaju klasycznego kontrapunktu” ${ }^{21}$, dającego wyjątkową elastyczność warsztatową; Krzysztof Penderecki - wzorem swojego mistrza, Franciszka Skołyszewskiego, całe życie był wierny klasycznemu kontrapunktowi, bez cudzysłowu ${ }^{22}$. Znamienne, że także w kontaktach z dźwiękiem elektronicznym szukał zawsze zarówno nowych sposobów rozbudowania formy, jak i wzmocnienia środków ekspresywnych. W Kanonie na orkiestrę smyczkową i 2 taśmy, wykorzystując konwencję live electronics, zaprezentował - paradoksalnie, w przestrzennym zwielokrotnieniu i czasowej kondensacji - wszystkie tradycyjne techniki kontrapunktyczne, z 208-głosowym strettem włącznie. Z kolei w Psalmus 1961 skupił się - na modłę stockhausenowskiego Gesang der Jünglinge - na eksploracji możliwości przekształcania wyłącznie materiału wokalnego ${ }^{23}$. Ekspresję tego ostatniego utworu w czasie premierowych wykonań określono jako „wprost wstrząającą" ${ }^{24}$. Poszukiwanie nowych technik u twórcy Trenu ofiarom Hiroszimy zawsze wiązało się z osiąganiem nowych środków wyrazu, nigdy z wyrazu w swojej sztuce nie zrezygnował, toteż z jego nazwiskiem zaczęto łączyć dość paradoksalną formułę „sonoryzm ekspresywny” ${ }^{25}$. Jednakże warto zwrócić uwagę na jeszcze inny aspekt tego czasu: szukanie „prawdziwej natury” dźwięku, odkrywanie jego specyficznej metafizyki.

Wczesne lata 60. to dla twórcy Trenu czas nie tylko błyskotliwego debiutu, ale też intensywnego rozwoju technicznego wspartego filozoficzno-estetyczną refleksją. Biograf opisując ów moment, dwukrotnie używa określenia „bieg” - pierwszy raz o trzymiesięcznej podróży przez całe Włochy, gdzie - jak zauważa - Penderecki „czuł się u siebie w domu, w swoim kulturowym, śródziemnomorskim

20 Na początku lat 60. współpracował intensywnie ze Studiem Eksperymentalnym Polskiego Radia w Warszawie kierowanym przez Józefa Patkowskiego.

${ }_{21}$ Wywiad dla „Paris New Music Review” 1993, za: D. Gwizdalanka, Historia muzyki, t. 3, Kraków 2009, s. 187.

22 Co godne uwagi, to właśnie Franciszek Skołyszewski jako pierwszy zwrócił uwagę młodemu Krzysztofowi na nowo rozwijające się media elektroniczne.

23 Realizacji partii wokalnej dokonała wybitna interpretatorka nowej muzyki, Halina Łukomska.

24 K.H. Wörner, Arnold Schoenberg and the Theater, „Musical Quarterly” 48 (1962) no. 1, s. 93121, cyt. za: M. Tomaszewski, Penderecki. Bunt i wyzwolenie, t. 1, s. 159.

25 Pojęcie to wprowadził Mieczysław Tomaszewski w pracy Sonorystyczna ekspresywność $i$ alegoryczny symbolizm: symfonia „szkoty polskiej”, w: M. Tomaszewski, Interpretacja integralna dzieta muzycznego. Rekonesans, Kraków 2000. 
matrimonium" 26 , drugi zaś - o błyskawicznym wchłonięciu wszystkich nowoczesnych technik od dodekafonii po aleatoryzm „kursem przyspieszonym” ${ }^{27}$. Można powiedzieć, że w każdym kolejnym utworze Penderecki posuwał się dalej w badaniach nad naturą dźwięku, poszerzając spektrum percepcji, a nawet, jak pisano wówczas: „otwierając uszy” ${ }^{28}$. Nic dziwnego, że okres ów przyniósł utwory, których tytuły wprost wskazywały na przedmiot jego zainteresowań badawczych: Wymiary czasu i ciszy (1960) oraz De natura sonoris I i II (1966, 1971). Pierwszy, według samego kompozytora, stanowił swoistą transpozycję założeń kompozycji malarskiej Paula Klee i Yvesa Kleina na materię muzyczną, dwa pozostałe natomiast nawiązywały w tytule do ulubionego przez Pendereckiego traktatu Lukrecjusza De rerum natura. Słuchając tych stosunkowo drobnych utworów, ma się wrażenie obcowania $\mathrm{z}$ istotnym eksperymentem dokonującym się w materii dźwiękowej. Wszelkie jakości przyjęte w dotychczasowej muzyce za punkt oparcia zostają doprowadzone do ekstremów, a następnie - w swoistej muzycznej dialektyce spolaryzowane i zsyntetyzowane. W zakresie wysokości stosowane są najwyższe i najniższe możliwe do wykonania dźwięki, w zakresie dynamiki - skrajne stopnie z ciszą włącznie, w zakresie faktury - kontrast możliwie najbardziej statycznych „wibrujących płaszczyzn” z kalejdoskopową zmiennością na wzór „kart tarota" ${ }^{29}$. Tego typu kontrast wsparty jest wydatnie przez bogatą paletę kolorystyczną, w której znajdują się zarówno niekonwencjonalne sposoby artykulacji, jak i nowe instrumenty, przede wszystkim perkusyjne.

Nie będzie może nadużyciem stwierdzenie, iż w ten właśnie sposób, dochodząc do granic możliwości empirycznych, Penderecki zaczął odkrywać specyficzną metafizykę dźwięku: jako czegoś więcej niż proste parametry. Echo tego odkrycia, a raczej potwierdzenia swoich głębokich przekonań, pobrzmiewa w znanej wypowiedzi: „nie konstruuję brzmienia dla samego brzmienia” ${ }^{30}$.

\section{Muzyczny czas i przestrzeń}

Wiele już pisano o przesłaniu dzieł Krzysztofa Pendereckiego, o wielkich tematach i treściach istotnych. W rozmowach lusławickich z przyjacielem, Mieczysławem

\footnotetext{
26 M. Tomaszewski, Penderecki. Bunt i wyzwolenie, t. 1, s. 132.

27 M. Tomaszewski, Penderecki. Bunt i wyzwolenie, t. 1, s. 133.

28 T.A. Zieliński: „Kompozytor «otwiera nam uszy» na niedostrzegane dotąd niuanse brzmienia wynikające $z$ artykulacji, dynamiki, zestawu barw instrumentalnych, gęstości masy dźwiękowej itp.”, za: M. Tomaszewski, Penderecki. Bunt i wyzwolenie, t. 1, s. 131.

29 M. Tomaszewski, Penderecki. Bunt i wyzwolenie, t. 1, s. 139.

30 K. Penderecki: „Przecież w każdym utworze staram się znaleźć nowe brzmienie, ale to nigdy nie jest brzmienie dla brzmienia” (M. Tomaszewski, Penderecki. Bunt i wyzwolenie, t. 1, s. 131).
} 
Tomaszewskim, mówi wprost: „Mnie interesują tematy wielkie i uniwersalne. I zawsze wydawało mi się, że szkoda czasu na drobiazgi” ${ }^{31}$. Daleki od panegiryzmu Bogusław Schaeffer zwrócił uwagę na istotny rys osobowości twórcy: „Pisanie oper, pasji, koncertów solowych (...), pisanie na wielkie, nieraz olbrzymie zespoły wymaga świadomości, że się taki temat czy takie zamierzenia udźwignie. Takiej świadomości kompozytorowi nie brakło nigdy" ${ }^{32}$. Warto jednak w związku z tym zwrócić uwagę na pewną stałą i ważną, choć mniej dostrzeganą cechę jego osobowości twórczej: doskonałą świadomość czasu i przestrzeni, w znaczeniu zarówno realnym, jak i muzycznym. Wspominając genezę Pasji wg św. Łuka$s z a$, kompozytor najpierw uświadomił sobie, że w tym okresie nigdy jeszcze nie napisał większej formy: „(...) do tego czasu pisałem tylko małe utwory. Najdłuższy mój utwór miał nie więcej niż dziewięć czy dziesięć minut”" ${ }^{33}$. Wyczucie czasu dało znać o sobie w obydwu znaczeniach: po pierwsze, kompozytor spostrzegł w pojawiającej się propozycji szansę na wejście w nowy etap swojej drogi twórczej - zmierzenie z wielką formą, która z kolei będzie potrzebowała odpowiedniego czasu, by udźwignąć wielki temat. Dalej, przy najbliższej okazji pojechał do miejsca prawykonania - katedry w Münster, i zdał sobie sprawę z wyjątkowo długiego (około dwunastosekundowego) pogłosu. Zaplanował zatem w Pasji wiele - jak to ujął - pustych miejsc na wybrzmienie ${ }^{34}$. Zresztą cała struktura owego dzieła, uznanego - nie od razu, lecz jednomyślnie - za arcydzieło, związana jest ze specyficzną dynamiką hic et nunc. Może warto przypomnieć okoliczność nieoczywistą - to właśnie Pasja wg św. Eukasza otwiera listę wielkich dzieł wokalno-instrumentalnych, w których owa dramatyzacja stanowi rys najsilniejszy. Recenzent jednego z najnowszych wykonań Pasji zwraca uwagę na dający do myślenia szczegół: „Zwłaszcza mroczna, obrazowa scena w Ogrójcu pozwalała zrozumieć późniejszy sukces kompozytora jako twórcy operowego. Fragment ten to istna scenografia namalowana dźwiękami (...)"35. Wyobraźnia kompozytora kreowała, by tak rzec, od zawsze, wieloplanową przestrzeń i polifonicznie biegnące strumienie czasu.

Bohdan Pociej, próbując w latach 80. ująć istotę stylu religijnego kompozytora, pisał:

31 K. Penderecki, Rozmowy lustawickie, t. 1, rozmawiał M. Tomaszewski, Olszanica 2005, s. 68, za: M. Tomaszewski, Penderecki. Bunt i wyzwolenie, t. 1, s. 18.

32 B. Schaeffer, Kompozytorzy XX wieku, Kraków 1990, t. 2, s. 185.

33 B. Schaeffer, Kompozytorzy XX wieku, s. 193.

34 B. Schaeffer, Kompozytorzy XX wieku, s. 194.

35 K. Komarnicki, Pasja Pendereckiego, http://beethoven.org.pl/recenzje/pasja-pendereckiego (31.03.2021). 
Swoim dynamicznym talentem Penderecki chce sacrum przede wszystkim pokazać - w wielkich rozmiarach czasowych, w rozległych przestrzeniach: głosy ludzkie, instrumenty, orkiestry, chóry, aktorzy, recytatorzy, scena wyobrażona i rzeczywista ${ }^{36}$.

Zarówno utwory zanurzone w liturgii, takie jak Pasja, obie Jutrznie, Magnificat, Polskie Requiem, Credo, jak i dzieła uznawane przez niektórych za pozostające poza obrębem sacrum, a przez innych - owo sacrum na sposób współczesny wyrażające: Diabty z Loudun, Dies irae, Kosmogonia, Raj utracony, Czarna maskapokazują, że rozmach ich autora wiąże się ze swobodą poruszania zarówno w muzycznym czasie, jak i przestrzeni. Różne strategie narracyjne Pendereckiego przywodzą na myśl nie tylko teatr, ale współczesną powieść czy film - rozmaite porządki czasoprzestrzenne krzyżują się i nakładają na siebie. Regina Chłopicka podkreśla, że kompozytor w dziełach tak różnych, jak Pasja i Raj utracony radykalnie kondensuje treść i dramatyzuje formę ${ }^{37}$. Jak zauważa: „Przedstawione modyfikacje tekstu prowadzą do skrócenia i kondensacji, a także przez przesunięcie punktu ciężkości z narracji na dialog, do jego dramatyzacji" ${ }^{38}$. Bodaj najbardziej zaskakującą próbą jest nadanie dramatycznego ładunku pozornie najmniej się do tego nadającemu, dogmatycznemu tekstowi Credo. Dokładniejsza analiza samego tekstu liturgicznego oraz jego kunsztownego opracowania przez kompozytora pokazuje jednak, że Penderecki wydobywa z Wyznania Wiary moment dramaturgiczny, głęboko ukryty w dziewięciu czasownikach dotyczących Chrystusa, które streszczają centrum tego, co Kościół nazywa historią zbawienia ${ }^{39}$.

Dla Krzysztofa Pendereckiego liturgia nigdy nie jest teologiczną abstrakcją. Zafascynowany wspominał swój udział w ekstatycznych procesjach prawosławnej Wielkanocy, „gdzie każdy uderzał w to, co ma. Ta turba tam żyje (...) - to jest ekstaza, przeżycie” ${ }^{40}$, a o wizji turby w swojej Pasji mówił: „Chodziło mi o to, aby widz poprzez napięcie i dramatyzm muzyki został włączony w sam środek wydarzeń - jak w średniowiecznym misterium, gdzie nikt nie stał z boku" ${ }^{41}$.

\footnotetext{
36 B. Pociej, Sacrum w polskiej muzyce wspótczesnej, w: Przemiany techniki dźwiękowej, stylu i estetyki w polskiej muzyce lat 70., red. L. Polony, Kraków 1986, s. 54.

37 R. Chłopicka, Krzysztof Penderecki między sacrum a profanum, s. 32, 86.

38 R. Chłopicka, Krzysztof Penderecki między sacrum a profanum, s. 32.

39 Por. K. Cyran, Wielka synteza - od dogmatu do dramatu. O Credo Krzysztofa Pendereckiego, „Teoria Muzyki” (2019) nr 14, s. 95-96.

40 M. Tomaszewski, Penderecki. Bunt i wyzwolenie, t. 1, s. 226.

41 R. Chłopicka, Krzysztof Penderecki między sacrum a profanum, s. 31.
} 
A jednak u twórcy Polskiego Requiem w każdą, nawet najbardziej intensywną actio, wkracza moment contemplatio, który odnosi do wymiaru rozgrywającego się ponad wydarzeniami - wymiaru tajemnicy ${ }^{42}$.

\section{4. „Gość z innego świata”}

Patrząc na twórczość Krzysztofa Pendereckiego jako rozdział już niestety zamknięty, chce się dopowiedzieć, że oprócz siły wielkich tematów i wielkich tekstów wierzył, a przede wszystkim - by tak rzec - praktykował moc samej muzyki. Jak wielu kompozytorów współczesnych, oskarżany był o swoisty „kulturowy szantaż” polegający na wykorzystaniu znaczących tekstów kultury, z którymi kontakt miał jakoby automatycznie zrodzić arcydzieło, uwznioślające warstwę muzyczną. Oskarżenia owe, rzucane zazwyczaj z poziomu publicystyki, chybiały podwójnie: po pierwsze, nie brały pod uwagę maestrii twórcy Pasji i Raju utraconego w posługiwaniu się tekstem literackim i nadawania każdemu słowu odpowiedniej wagi. Zagadnienie retoryki muzycznej, wskrzeszonej przez Pendereckiego, a przez niektórych zwanej neoretoryką, domaga się z pewnością osobnego studium. Druga kwestia, choć może nawet ważniejsza, wydaje się mniej zauważana: otóż wśród licznych wypowiedzi kompozytora o muzyce znaleźć można szczególną grupę: bardzo rzadkie i nieliczne prywatne muzyczne „objawienia”, zaskakujące pewnością oglądu, choć poruszające się po materii wcale nieuchwytnej. Kwintet smyczkowy C-dur (D 596) Franciszka Schuberta nazwał „największą muzyką kameralną, jaka w ogóle może istnieć” ${ }^{33}$, o Chopinie mówił: „on miał wszystko, łatwość pisania melodii, której nikt nie miał z jemu współczesnych” ${ }^{44}$, u Brucknera zrazu fascynowały go „szeroki oddech, długie ekspozycje i niekończące się przetworzenia" ${ }^{45}$ i nagle przychodził moment stwierdzenia: „Mahler szukał Boga, Bruckner Go znalaz””6

Kiedy mowa o doświadczeniu boskości w samej substancji muzycznej, i kiedy wywołane zostają te właśnie, a nie inne nazwiska, trudno pominąć myśl niezwykle ważną, choć ledwo zasygnalizowaną - zresztą jak zwykle w paradoksalnej

42 Szczególne momenty, określane przez M. Tomaszewskiego jako „moment epifaniczny”, to np. Stabat mater w Pasji wg św. Eukasza (1965), Agnus Dei w Polskim Requiem (1984), De profundis $w$ Siedmiu bramach Jerozolimy (1996), Et incarnatus $w$ Credo (1998).

43 Muzyka Krzysztofa Pendereckiego. Poetyka i recepcja, red. M. Tomaszewski, Kraków 1996, s. 117.

${ }^{4}$ Krzysztof Penderecki, film z cyklu Portrety Komitetu Honorowego 17. Międzynarodowego Konkursu Pianistycznego im. Fryderyka Chopina, produkcja Narodowy Instytut Fryderyka Chopina 2015, https://www.youtube.com/watch?v=t_KgvpzDMO4\&t=106s (31.03.2021).

45 K. Penderecki, Rozmowy lustawickie, t. 1, s. 133.

46 K. Penderecki, Rozmowy lustawickie, t. 1, s. 153. 
formie - przez Henryka Mikołaja Góreckiego: „Jednej rzeczy nie lubię: sacrum i profanum, nie lubię tego podziału. Bo czy Chopin jest profan? Czy Schubert jest profan? Najprostsza piosenka Schuberta jest dla mnie niesamowitym sacru$\mathrm{m}^{\text {” }}{ }^{7}$. W ostatnich latach życia Henryk Mikołaj Górecki jako jeden z centralnych motywów swojej autorefleksji przywoływał słowa Leszka Kołakowskiego „muzyka to gość z innego świata” ${ }^{48}$. Penderecki innymi słowami - a przede wszystkim muzyką - zdaje się wyrażać tę samą myśl.

\section{Musica vera}

Interpretacja problematyki treści przesłania dzieł Krzysztofa Pendereckiego układa się w kilka zasadniczych nurtów. Jeden z nich wiedzie wzdłuż linii wyznaczonej przez Pasję i Dies irae aż do Polskiego Requiem. Dziś zapomina się, że zarówno tematyka utworów, jak i dołączone do nich dedykacje stanowiły „znak sprzeciwu” względem systemu totalitarnego i akt osobistej odwagi twórcy. Nie były to wówczas postawy ani łatwe, ani oczywiste. Mieczysław Tomaszewski słusznie przypomina, że Penderecki był pierwszym kompozytorem w tzw. bloku komunistycznym, który odważył się podjąć tematykę sakralną. Po długim okresie milczenia wymuszonego wojną i czasem socrealizmu Pasja wedtug św. Eukasza w pewnym sensie „eksplodowała” w kulturze polskiej, łamiąc niepisane tabu wśród kompozytorów ${ }^{49}$. Penderecki często przypominał, że sięgnął po archetyp pasji nie tylko po to, by wypowiedzieć mękę i śmierć Chrystusa, ale również męczeństwo Oświęcimia. Z kolei - jak podaje Tomaszewski - kompozytor w swoich niektórych wypowiedziach po latach zdawał się żałować, że zbyt silnie związał Polskie Requiem $\mathrm{z}$ historią, z dramatycznym „tu i teraz”, co jego zdaniem zagrażało zmieszaniem porządków sztuki i publicystyki:

A jednak - kontynuuje biograf - to właśnie stanowi o niepowtarzalnej odmienności [Polskiego Requiem] (...). Spełniło [ono] zadanie w sferze wyższej niż czysto estetyczna. Sytuacja przywodzi wprost na myśl frazę z Przestania Pana Cogito: Ocalałeś nie po to aby żyć / Masz mało czasu trzeba dać świadectwo ${ }^{50}$.

\footnotetext{
47 H.M. Górecki, Muzyka jest rozmową, rozmowa z A. Satyłą i K. Cyranem, „Jubinalia” (pismo studentów AMKP w Krakowie) 2008, nr 4, pełna wersja w posiadaniu autorów.

48 H.M. Górecki, Wystapienie doktora honoris causa, przemówienie z okazji przyznania doktoratu honoris causa Akademii Muzycznej w Krakowie, 12.05.2008 (faksimile rękopisu), „Teoria Muzyki” (2013) nr 3, s. 103-118.

49 Por. M. Tomaszewski, Penderecki. Bunt i wyzwolenie, t. 1, s. 192.

50 M. Tomaszewski, Penderecki. Bunt i wyzwolenie, t. 2: Odzyskiwanie raju, Kraków 2009, s. 94 (Kompozytorzy Polscy XX Wieku).
} 
Kwestie związane z kategorią świadectwa rozumianą jako element postawy twórczej w konfrontacji z grozą historii rozważa Tomaszewski w niezwykle ważnym dla muzyki polskiej tekście O twórczości zaangażowanej: muzyka polska 1944-1994 między autentyzmem a panegiryzmem ${ }^{51}$. Stawia on tezę, iż wartościowanie sztuki w systemach totalitarnych musi się odnieść do kontekstu historycznego, a więc szerszego niż artystyczny. Traktując utwór muzyczny jako hołd złożony wartościom, w zależności od typu wartości i autentyczności hołdu, autor wprowadza rozróżnienia na twórczość autentyczną i retoryczną, hiperboliczną i panegiryczną. Co zadziwiające, Krzysztof Penderecki, przechodząc przez wszystkie zakręty historii, na przekór zewnętrznym przeciwnościom, w swoich największych dziełach składał autentyczny hołd wartości pozytywnej, stojąc po stronie twórczości autentycznej dookreślonej przez Tomaszewskiego jako musica vera ${ }^{52}$.

\section{Credo}

Swoistą summą twórczości religijnej Krzysztofa Pendereckiego stało się Credo. Dzieło silnie obecne w kulturze, wielostronnie interpretowane, jawi się jako synteza zarówno własnych, stosowanych od czterdziestu lat technik kompozytorskich, „uporządkowanych i zhierarchizowanych" ${ }^{53}$, jak i synteza „charakterów sacrum” ${ }^{54}$ odcieni pobożności liturgicznej i ludowej, wspólnotowej i osobistej, tradycyjnej i współczesnej.

Warto zwrócić uwagę na tę ostatnią koncepcję, przedstawiającą w bardzo szerokim ujęciu refleksję nad „charakterami sacrum” znajdującymi odzwierciedlenie w twórczości religijnej. Jej autor - Mieczysław Tomaszewski - dla odczytania znaczenia i sensu danego charakteru wprowadza rozróżnienia wzięte z metod strukturalistycznych, szczególnie w ujęciu Algirdasa Greimasa ${ }^{55}$ (zob. Tabela 1). Idąc tropem owej refleksji, Credo należy ustawić zdecydowanie po stronie racjonalnego i zobiektywizowanego doświadczenia sacrum. Jednak kompozytor zarówno poprzez teksty dodatkowe, jak i warstwę muzyczną, niejako „uzupełnia” Wyznanie

51 M. Tomaszewski, Interpretacja integralna, s. 141-149. Autor z jednej strony nawiązuje do średniowiecznej tradycji (Johannes Tinctoris) przypisywania muzyce wielorakich funkcji duchowych, etycznych, znacznie szerszych niż jedynie estetyczna, z drugiej strony wspiera się najnowszymi odkryciami strukturalizmu na temat funkcji języka (Roman Jakobson).

52 Por. M. Tomaszewski, Interpretacja integralna, s. 142.

53 R. Chłopicka, Krzysztof Penderecki między sacrum a profanum, s. 205.

54 K. Cyran, Wielka synteza, s. 106-107.

55 Sama koncepcja „charakterów sacrum” pochodzi od Mieczysława Tomaszewskiego. Wyłożył ją w artykule Muzyka wobec sacrum. Próba rozeznania, w: Olivier Messiaen we wspomnieniach i w refleksji badawczej, red. M. Szoka, R.D. Golianek, Łódź 2009. 
Wiary - oczywiście, w wymiarze subiektywnym, właściwym dla pobożności osobistej:

\begin{tabular}{|l|l|}
\hline $\begin{array}{l}\text { Tekst Wyznania Wiary- } \\
\text { cechy w ujęciu „syndromu charakterów sacrum” } \\
\text { M. Tomaszewskiego }\end{array}$ & $\begin{array}{l}\text { Credo K. Pendereckiego - } \\
\text { cechy w ujęciu ,syndromu charakterów sacrum” } \\
\text { M. Tomaszewskiego }\end{array}$ \\
\hline fideistyczny & $\begin{array}{l}\text { fideistyczny ORAZ mistyczny } \\
\text { (liryka instrumentalna) }\end{array}$ \\
\hline dogmatyczny & $\begin{array}{l}\text { dogmatyczny ORAZ tradycjonalny } \\
\text { (cytaty z pieśni tradycyjnych) }\end{array}$ \\
\hline refleksyjny & $\begin{array}{l}\text { refleksyjny ORAZ spontaniczny } \\
\text { (partie chóru dziecięcego oraz wybrane sola wokalne) }\end{array}$ \\
\hline racjonalny & $\begin{array}{l}\text { racjonalny ORAZ emocjonalny } \\
\text { (ogólnie: tekst a muzyka) }\end{array}$ \\
\hline
\end{tabular}

Tabela 1. Porównanie jakości konstytutywnych tekstu Wyznania wiary oraz Credo K. Pendereckiego z wykorzystaniem kategorii „charakterów sacrum” Mieczysława Tomaszewskiego (oprac. Krzysztof Cyran) ${ }^{56}$.

Bardziej szczegółowy wgląd w rozmaite warstwy dzieła przekonuje zatem, że w poszczególnych momentach Credo odzywają się niejako wszystkie charaktery sacrum, o których mówił Tomaszewski. Można uznać więc utwór Krzysztofa Pendereckiego za syntezę owych charakterów.

Jak pokazuje jego geneza, Credo stało się również syntezą treści całej Mszy - rozrastając się i zastępując pierwotnie zamówiony cykl mszalny. Kompozytor zresztą od początku tak właśnie widział rolę swojego utworu: „Credo jest najważniejszym tekstem w całej Mszy, znajduje tu bowiem odbicie każda z myśli zawartych w jej pozostałych częściach”57. A kończąc utwór wiosną 1998 roku pisał:

Było dla mnie jasne, że Credo będzie główną częścią [Mszy] i [dlatego] włączyłem również do niej dodatkowe teksty. Jednak im dłużej nad nią pracowałem, tym jaśniejsze stało się, że dalsze części [Mszy] nie są już konieczne

56 Tabela i jej opis pochodzą z: K. Cyran, Wielka synteza, s.106.

57 R. Robinson, Krzysztof Penderecki's Credo (1996-98): a brief introduction, w: Krzysztof Penderecki's music in the context of the $20^{\text {th }}$-century theatre: studies, essays and materials, ed. T. Malecka, Kraków 1999, s. 63. 
dla uzupełnienia całości. Wszystkie pomysły, które miałem na całą Mszę, włączyłem obecnie do Credo $(\ldots)^{58}$.

Nie należy zapominać, że tego typu dzieło prowokowało pytania wprost o wiarę samego twórcy. Odpowiadał zwięźle - i we właściwy sobie sposób: „Kiedy w wieku 65 lat pisze się Credo, znaczy to przecież, że się wierzy, czyż nie tak?59”. Dopowiadał też oczywiście: „[Credo] to coś, w co trzeba uwierzyć lub odrzucić w całości. Nie można zaakceptować go tylko częściowo" " . A po prawykonaniu, które okazało się wielkim sukcesem, powiedział: „Jest to utwór tego rodzaju, jaki się komponuje jeden raz w swoim życiu" ${ }^{61}$.

\section{Pytać o najważniejsze}

Gdy spojrzeć na twórczość Krzysztofa Pendereckiego in extenso, w perspektywie ponad sześciu dekad, widać wyraźnie, iż wychodząc z jasno określonych chrześcijańskich korzeni, budował - i odbudowywał - niezwykle szeroką przestrzeń metafizyczną, otwartą na dialog, tak w sensie ekumenicznym jak i ogólnoludzkim, pytając niestrudzenie o sprawy najważniejsze - Boga, człowieka, dobro, zło, prawdę i wolność. Zwraca na to uwagę Andrzej Tuchowski:

Jakimkolwiek językiem muzycznym przemawia Penderecki, ze zdumiewającą konsekwencją powraca on do fundamentalnych kwestii etycznych, tak jakby oczekiwał, iż w ten sposób poruszy jak największą liczbę słuchaczy, zmuszając ich do refleksji. Uwikłanie Pendereckiego w złożone dylematy współczesności, które (...) okazują się dylematami wszech czasów, ukazuje prawdziwe - bo trwałe - oblicze humanisty, któremu obca jest wszelka splendid isolation, który dostrzega społeczny wymiar swej sztuki ${ }^{62}$.

58 K. Penderecki, List do Helmutha Rillinga, drukowany w książeczce do CD: K. Penderecki, Credo, wyk. H. Rilling (dir.), Hänssler-Verlag, Stuttgart 1998.

59 I. Stephan, wywiad z K. Pendereckim, 13 czerwca 2003 r., Oldenburg, za: H. Loos, Credo Krzysztofa Pendereckiego $w$ tradycji kompozycji mszalnych, tłum. M. Kozłowska, w: Krzysztof Penderecki - muzyka ery intertekstualnej. Studia i interpretacje, red. M. Tomaszewski, E. Siemdaj, Kraków 2005, s. 221.

60 R. Robinson, Krzysztof Pendereckis Credo, s. 62.

${ }_{61}$ M. Tomaszewski, Penderecki. Bunt i wyzwolenie, t. 2, s. 255.

62 A. Tuchowski, "Czytalne” a "pisalne”- etyczny ksztatt twórczości Krzysztofa Pendereckiego, w: Muzyka ery intertekstualnej, s. 113. 
Regina Chłopicka w swoim kompendialnym studium Krzysztof Penderecki między sacrum a profanum wybrała do analizy jedenaście najważniejszych dzieł kompozytora, grupując je w kategoriach „muzyka sakralna” oraz „muzyka świecka”, przede wszystkim na podstawie użytych tekstów literackich ${ }^{63}$. Jednakże już sama analiza owych tekstów prezentuje niezwykle szeroką panoramę odniesienia do wartości religijnych, moralnych, ogólnohumanistycznych ${ }^{64}$. Pomijając utwory stricte religijne, których aspekty ważne dla kompozytora zostały omówione w poprzednich podrozdziałach, warto zwrócić szczególną uwagę na przesłanie czterech oper Pendereckiego. Łączy je nie tylko - jak podkreśla Chłopicka - przewijający się temat śmierci, ale też w centrum Diabtów z Loudun, Raju utraconego czy Czarnej maski - pozostaje człowiek uwikłany w złożone dylematy moralne, dalekie od teologicznej konfesyjności czy czarno-białego moralizatorstwa. A nawet Ubu Król, któremu nazbyt pochopnie przypięto łatkę postmodernizmu, choć muzycznie często uwodzi lekkością i prowadzi w sferę buffo, w rzeczywistości również odnosi się do spraw najważniejszych, tyle że à rebours: portretuje bowiem niespotykanych dotąd rozmiarów kataklizm ideowy - zanegowanie, wyśmianie i spłycenie najważniejszych wartości tradycyjnego kanonu kultury. Należy dodać: portretuje ów kataklizm ze wszystkimi jego konsekwencjami. Stefan Morawski pisząc o sztuce ponowoczesnej zwraca uwagę na „bezgraniczną tolerancję wobec konkurujących ze sobą wartości i bezwartości”" lizmu, a hasło nieograniczonej swobody staje się postmodernistycznym idolem ${ }^{67}$.

63 R. Chłopicka, Krzysztof Penderecki między sacrum a profanum, s. 15. Owe utwory to: 1 . Muzyka sakralna: Pasja wg św. Łukasza, Diabty z Loudun, Jutrznia, Magnificat, Raj utracony, Polskie Requiem, Siedem bram Jerozolimy i Credo (ujęte w jednym podrozdziale); 2. Muzyka świecka: Wymiary czasu i ciszy, Czarna maska, Ubu Król.

${ }_{64}$ Autorka wprowadza następujące kategorie: I. Muzyka sakralna: 1) tematyka religijna, teksty biblijne i liturgiczne; a) krąg liturgii łacińskiej: Pasja wg św. Eukasza, Magnificat, Polskie Requiem, Siedem bram Jerozolimy, Credo; b) krąg liturgii prawosławnej: Jutrznia I i II; 2) tematyka religijna, teksty literackie nie związane z liturgią, charakter misteryjny: Raj utracony; 3) tematyka świecka, teksty literackie - do sfery sacrum odnosi rodzaj interpretacji tematu i generalne przesłanie: Diabty z Loudun; II. Muzyka świecka: 1) tematyka świecka, teksty literackie, dominuje wiara w człowieka i akceptacja wartości humanistycznych: Kosmogonia, Dies irae; 2) tematyka świecka, teksty literackie - zakwestionowane lub zanegowane są wartości humanistyczne i sens egzystencji człowieka: Czarna maska, Ubu Król; 3) brak odniesień do sfery wartości nadestetycznych: Wymiary czasu i ciszy (por. Tabela: Muzyka świecka, w: R. Chłopicka, Krzysztof Penderecki między sacrum a profanum, s. 15).

65 S. Morawski, Postmodernizm - jak go rozumiem i dlaczego nie lubię?, „Integracje” (1991) nr 27, s. 42, za: M. Piotrowska, Kanon i postmodernizm, „Muzyka” (1997) nr 1, s. 17.

66 S. Morawski, Postmodernizm, s. 42.

67 S. Morawski, Postmodernizm, s. 42. 
Penderecki, stając zawsze po stronie tradycyjnych wartości, używając wybranych elementów sztuki postmodernizmu (eklektyzm, pastisz, ironia, bunt, „styl niski”), pokazuje ów świat jako przerażający - i odrażający. Cztery lata przed premierą $U b u$, cytował w Monachium diagnozę Czesława Miłosza:

Główną cechą naszych wspaniałych czasów jest „zastąpienie dramatu obojętnością”, anihilacja: „Rozpacze, krzyki, prawowania się z Bogiem, zadawanie pytań o rodowód Zła, wszystko to umilkło i zagadnienia, z którymi człowiek borykał się przez milenia, zostały sprowadzone do błąkań się języka, z którego wygnano pojęcie prawdy albo nieprawdy"68.

Mówiąc natomiast o swojej muzyce w całościowym ujęciu, przywołał zdanie Gustawa Mahlera: odnosi się ona do „całego człowieka - czującego, myślącego, oddychającego, cierpiącego"69. Cała twórczość Pendereckiego zdaje się potwierdzać owo zdanie. Jak każdy wielki twórca, chętniej i mocniej wypowiadał się przez samą sztukę niż przez komentarz. Jednak jego teksty stanowią również istotną część autorefleksji w muzyce polskiej ostatniego stulecia.

Jego artystyczna podróż, o niemal kosmicznych trajektoriach, obejmowała dialektyczną drogę od abstrakcyjnej liczby do konkretnego, namacalnego dźwięku, od czasoprzestrzennego konkretu hic et nunc do muzycznych „przestrzeni i czasów wyobrażonych", wreszcie - od wielkich tekstów kanonu kultury do nieuchwytnej tajemnicy samej muzyki: „gościa z innego świata”.

Można powiedzieć, nieco przewrotnie, że Penderecki swą sztuką budował taką właśnie przestrzeń metafizyczną, w której każdy gość przychodzący po dobrej woli będzie mile widziany. Niewypowiedziana wprost, a stale obecna w jego partyturach, pojawia się idea wzajemnego szacunku dla własnego, osobowego wymiaru sakralnego, daleka od karykaturalnego relatywizmu, zakorzeniona w chrześcijaństwie, o czym wielekroć wspominał. Jak w lusławickim ogrodzie-labiryncie, jego twórczość bardziej otwierała coraz szersze przestrzenie piękna i wskazywała nowe nieodkryte szlaki, niż nakłaniała do pójścia którymkolwiek z nich.

W niezwykle trudnym dla ludzkiego ducha XX wieku Krzysztof Penderecki miał siłę i odwagę stanąć po stronie musica vera. To wydaje się najważniejsze w mnogości stylistyk, technik, inspiracji z rozmaitych dziedzin sztuki, działalności dyrygenckiej, pedagogicznej i społecznej, składających się na iście renesansową osobowość twórcy.

Jak to z wielką sztuką się dzieje, przyszłość z pewnością odkryje w niej kolejne nowe warstwy. Dobrze, że ta muzyka zostanie z nami.

68 K. Penderecki, Labirynt czasu, s. 47.

69 K. Penderecki, Labirynt czasu, s. 60. 


\section{Abstrakt \\ Wymiary czasu, dźwięku i ciszy. Krzysztof Penderecki i sacrum}

Artykuł omawia wybrane aspekty duchowego wymiaru muzyki Krzysztofa Pendereckiego w perspektywie metafizycznej, nakreślonej przez samego kompozytora w wypowiedziach kluczowych dla jego autorefleksji. „Odbudowanie przestrzeni metafizycznej, strzaskanej przez kataklizmy XX wieku” zakłada przemyślenie podstaw dotychczasowej kultury oraz poszukiwanie nowych środków wyrazu. Autor, odnosząc się do ponad sześciu dekad działalności twórcy Polskiego Requiem, skupia się na kilku kluczowych wątkach, takich jak: liczba i parametr, czas i przestrzeń, metafizyka dźwięku, ethos dzieła i sacrum obecne w samej muzyce. Owa interpretacja stara się wydobyć mniej opisywane cechy muzyki Pendereckiego, stanowiące jednak w rozumieniu autora stały i ważny komponent we wszystkich okresach jego twórczości.

Stowa kluczowe: \#penderecki_credo, \#muzyka_nowa, \#muzyka religijna, \#muzyka_xx_ wieku, \#penderecki_pasja_wg_św_łukasza, \#przestrzeń metafizyczna, \#sacrum_profanum, \#wymiar_sakralny_człowieka, \#wymiary_czasu_i_ciszy

\section{Abstract}

Dimensions of Time, Sound and Silence. Krzysztof Penderecki and the Holy

The article discusses certain aspects of a spiritual dimension in the music of Krzysztof Penderecki, seen from a perspective by himself, inspired by his crucial statements about his own art. "Restoring of the metaphysical space, crushed by the $20^{\text {th }}$ century disasters" requires rethinking the principles of our culture as well as seeking new artistic means of expression. The author, referring to six decades of Polish Requiem creator's career, focuses on a few key ideas such as: number and parameter, time and space, metaphysics of sound, ethos of a work of art and holiness present in the music itself. This interpretation aims to throw light on less exposed features of Penderecki's music. However, in the author's opinion, these features form its constant and important component through all periods of his artistic biography.

Keywords: \#dimensions_of time_and_silence, \#20 $0^{\text {th }}$ ccent_music, \#metaphysical_space, \#new_music, \#penderecki_credo, \#penderecki_st_luke_passion, \#religious_music, \#sacrum_profanum, \#spiritual_dimension_human_being 


\section{Bibliografia}

Bramorski J., Teologiczno-estetyczne wyznaczniki sakralności dzieła muzycznego, „Pro Musica Sacra” (2013) nr 11, s. 11-22.

Bramorski J., Pieśń nowa człowieka nowego. Teologiczno-moralne aspekty muzyki w świetle myśli Josepha Ratzingera - Benedykta XVI, Gdańsk 2012.

Chłopicka R., Krzysztof Penderecki między sacrum a profanum, Kraków 2000.

Cyran K., „Kanon i postmodernizm” w twórczości religijnej kompozytorów polskich przetomu XX i XXI wieku, Kraków 2015 (niepublikowana praca doktorska pod kierunkiem prof. Teresy Maleckiej).

Cyran K., Wielka synteza - od dogmatu do dramatu. O Credo Krzysztofa Pendereckiego, „Teoria Muzyki. Studia, Interpretacje, Dokumentacje” 8 (2019) nr 14, s. 93-110.

Duchowość Europy Środkowej i Wschodniej w muzyce końca XX wieku, red. K. Droba, T. Malecka, K. Szwajgier, Kraków 2004.

Eliade M, Sacrum i profanum. O istocie religijności, tłum. R. Reszke, Warszawa 1999.

Górecki H.M., Wystapienie doktora honoris causa Akademii Muzycznej w Krakowie, 12.05.2008 (faksimile rękopisu), „Teoria Muzyki. Studia, Interpretacje, Dokumentacje" (2013) nr 3, s. 104-110.

Krzysztof Penderecki - muzyka ery intertekstualnej. Studia i interpretacje, red. M. Tomaszewski, E. Siemdaj, Kraków 2005.

Krzysztof Penderecki's music in the context of the $20^{\text {th }}$-century theatre: studies, essays and materials, ed. T. Malecka, Kraków 1999.

Penderecki K., Labirynt czasu. Pięć wyktadów na koniec wieku, Warszawa 1997.

Penderecki K., Rozmowy lustawickie, t. 1, rozmawiał M. Tomaszewski, Olszanica 2005.

Piotrowska M., Kanon i postmodernizm, „Muzyka” 42 (1997) nr 1, s. 5-30.

Pociej B., Sacrum w polskiej muzyce wspótczesnej, w: Przemiany techniki dźwiękowej, stylu i estetyki w polskiej muzyce lat 70., red. L. Polony, Kraków 1986.

Robinson R., Studies in Penderecki, vol. 2, Princeton-New Jersey 2003.

Sacrum i sztuka, Materiały z konferencji KUL Kościót a sztuka wspótczesna, red. N. Cieślińska, Kraków 1986.

Tomaszewski M., Interpretacja integralna dzieła muzycznego, Kraków 2000.

Tomaszewski M., Penderecki. Bunt i wyzwolenie, t. 1: Rozpętanie żywiotów, Kraków 2008 (Kompozytorzy Polscy XX Wieku).

Tomaszewski M., Penderecki. Bunt i wyzwolenie, t. 2: Odzyskiwanie raju, Kraków 2009 (Kompozytorzy Polscy XX Wieku).

Tomaszewski M., Muzyka wobec sacrum. Próba rozeznania, w: Olivier Messiaen we wspomnieniach i w refleksji badawczej, red. M. Szoka, R.D. Golianek, Łódź 2009.

Waloszek J., Teologia muzyki. Wspótczesna myśl teologiczna o muzyce, Opole 1997.

Zieliński T.A., Podstawy harmoniki nowoczesnej, Kraków 2009. 